\title{
ASSERTION FOR MONTELUKAST IN THE COVID-19 PANDEMICS?
}

\author{
ANDRA IULIA SUCEVEANU ${ }^{1 \#}$, LAURA MAZILU ${ }^{1}$, ADRIAN PAUL SUCEVEANU ${ }^{1}$, IRINEL \\ PAREPA $^{1}$, ION-BOGDAN DUMITRESCU $^{2} *$, CRISTINA MANUELA DRĂGOI ${ }^{2}$, ALINA \\ CRENGUȚA NICOLAE ${ }^{2}$, FLORIN BOTEA ${ }^{3}$, FELIX VOINEA ${ }^{1 \#}$, GEORGE TRAIAN \\ ALEXANDRU BURCEA-DRAGOMIROIU ${ }^{2}$
}

${ }^{I}$ Faculty of Medicine, "Ovidius” University of Constanța, Romania

2 "Carol Davila” University of Medicine and Pharmacy, Bucharest, Romania

${ }^{3}$ Liver Transplant and General Surgery Centre, Fundeni Intitute, 022338, Bucharest, Romania

*corresponding author: ion.dumitrescu@umfcd.ro

${ }^{\#}$ Authors with equal contribution.

Manuscript received: June 2020

\begin{abstract}
The ongoing pandemic coronavirus disease (COVID-19) is an infection caused by a newly discovered severe acute respiratory syndrome coronavirus 2 (SARS-CoV2). The treatment of COVID-19 patients represents a continuous challenge, no vaccine or specific antiviral therapy is yet available. International guidelines recommend the medical management based only on the first line physicians' short expertise, off-label approaches being admitted worldwide to limit and to decrease the infection devastating impacts on humans' health. A marketed drug used for asthma, known generically as montelukast, gives light in the attempt of clinicians during their efforts to combat SARS-CoV2 spreading. Even not yet approved by FDA or EMA for COVID-19 infection indication, many clinicians are raising-up the idea of turning attention and attempts to offlabel medical options like montelukast use, considering this drug an alternative or additive therapeutic approach for prevention and treating pulmonary distress.
\end{abstract}

\section{Rezumat}

Infecția pandemică cu coronavirus (COVID-19), aflată în plină desfășurare, este cauzată de coronavirusul sindromului acut respirator sever (SARS-CoV2). Tratamentul pacienților cu COVID-19 reprezintă o provocare continuă, în contextul în care nu există încă un vaccin sau o terapie antivirală specifică. Reglementările internaționale recomandă managementul terapeutic bazat pe expertiza medicilor de primă linie, abordările off-label fiind admise la nivel mondial pentru a limita şi a reduce impactul devastator al infecției asupra sănătăţii oamenilor. Montelukast, un medicament indicat în astmul bronşic, reprezintă o speranță în încercarea clinicienilor și în eforturilor lor de a combate avalanșa de efecte negative ale SARS-CoV2. Chiar dacă nu a fost încă aprobat de către FDA sau EMA pentru indicația patologiei infecțioase asociate COVID-19, mulți clinicieni avansează ideea de a îndrepta atenția către utilizarea acestei substanțe, considerând acest medicament o abordare terapeutică alternativă sau aditivă pentru prevenire şi tratarea afectării grave pulmonare.

Keywords: montelukast, COVID-19, leukotrienes, therapy

\section{Introduction}

The COVID-19 infection outbreak was initiated in Wuhan, China, in December 2019 [33, 35]. After its rapid spread, it becomes a major global concern, the outbreak being declared a pandemic on $11^{\text {th }}$ March 2020 by the World Health Organization. After 7 months, more than 15 million cases of COVID-19 have been reported in 215 countries and regions, and over 600,000 deaths were reported $[33,35]$. People are infected via small droplets from diseased people that are produced by sneezing, coughing, or talking, as well as by touching contaminated surfaces, the virus having the ability to survive hours or even days. Symptoms like cough, fever, asthenia, breath drawback, privation from smell or taste are being the first reported $[2,6]$. Severe and critical infections complicate the course of the disease, pneumonia, and acute respiratory distress syndrome dominating the clinical picture [33, 35]. The onset of symptoms becomes evident typically after five days from the infected exposure, but it can also manifest even after two weeks [29, 35]. Despite the tremendous efforts conducted in this direction, there is not yet discovered an etiologic treatment, no vaccine or specific antiviral treatments are available [21]. Preventive, symptomatic and supportive therapies are currently recommended $[10,26]$. For the curative purpose, many antiviral agents were considered in the attempt to limit the viral pathological effects on human health, the number of severe and critical cases, and not ultimately, to decrease the death rate [20, 23, 25]. Despite all medical and social efforts, COVID-19 infection continues to spread worldwide. At the same time, physicians, no matter their specialty, are focused 
on finding ways to stop the pandemic phenomena and to improve the outcome of severe and critical forms. International guidelines and off-label approaches are used through the physician's efforts to improve the respiratory and the altered general status of severe and critical patients. The amelioration of persistent cough following viral infection or whooping cough by using leukotriene blockade with montelukast represents a model for physicians to act in the case of SARSCoV2 infected patients, in their attempt to ameliorate the respiratory function [31, 32]. The present article focus on the premises of using montelukast in COVID19 infection and its possible benefits on COVID-19 pulmonary distress. Physicians recommending montelukast for COVID-19 infection are advocating their clinical judgment on a similar viral infection, like Influenza A virus, which demonstrated a good response to montelukast treatment due to its inflammatory modulatory effect $[8,11,34]$.

The highly dominant "cytokine storm" related with COVID-19 pathogenesis depicting the release of a plethora of pro-inflammatory cytokines as TNF- $\alpha$, IL-6, IL-1, IL-8, MCP-1 is incriminated for the prompt systemic organ collapse registered in critically ill patients. This is by no means a singular event, as the virus origins an enormous cell destruction and cellular debris accumulation that stimulates the inflammasomes, triggering a consecutive macrophage-derived "eicosanoid storm". At this stage, the organism is faced with a biological flood of pro-inflammatory lipid mediators, mainly prostaglandins and leukotrienes, which depict the massive local inflammation [12, 15].

New approaches for identifying better treatments for this disease recommend $10 \mathrm{mg} /$ day montelukast to prevent the infection of lung cells involved in respiratory gas exchanges, and to prevent the dysimmune inflammatory complications [17, 22, 37]. This purpose is based on their late expertise in the combat against COVID-19 infection. In light of this discovery, a new, statistically based clinical trial to test montelukast efficacy for COVID-19 infection is already proposed (NCT04389411) [11, 37].

\section{Montelukast modulatory potential upon the inflammation cascade}

Montelukast is a leukotriene (LT) receptor antagonist against the cysteinyl leukotriene $1\left(\right.$ CysLT $\left._{1}\right)$ receptor [13]. Leukotrienes are eicosanoids implicated in inflammation, of different types: cysteinyl group (CysLTs), LTB4, LTG4 and LTB5. CysLTs are primarily responsible with the inflammation by increasing the microvascular permeability. They also contract the bronchiolar smooth muscle and increase the mucus production. The mechanism of action involves the direct interaction with the CysLT receptors (1 and 2), from the G-coupled proteins family. Eicosanoids pathway is initiated when phospholipase A2 (cPLA2) hydrolyses arachidonic acid from lipid membranes [13].

The arachidonic acid released from the lipid structures may be converted into leukotrienes through 5lipoxygenase, or converted into prostaglandins and thromboxane through cyclooxygenases, or reinserted into the lipid membrane via Land's cycle or it may by oxidised with the cytochrome P450. Through intermediates that are fast transformed into prostaglandins, leukotrienes, lipoxins and other lipid inflammation mediators by specific enzymes, the $G$ protein-coupled receptors modulating the intracellular cAMP or calcium levels are activated, thus affecting the gene expression and cell functioning. Due to the unstable structure of most of the arachidonic acid derivatives, they are signalling molecules acting by autocrine and paracrine mechanisms [11, 13, 24].

Leukotrienes originate from the identical precursor as prostaglandins, but functionally act different, being predominately yielded by inflammatory cells. Once cellular activation prevails, cPLA2 and 5lipoxygenase (5-LOX) are rendered to the nuclear envelope.

LOX enzymes are a family of dioxygenases which facilitate the synthesis of 5-hydroperoxyeicosatetraenoic acid (5-HPETE). Namely, through the 5LOX, the arachidonic acid is converted to the unstable epoxide via a dehydration reaction, which further is oxidized to frame either 5-HETE or the leukotrienes. In the cytoplasm or nucleus, involving the A4 hydrolase, LTA4 is replaced by a potent chemoattractant, LTB4. But, in the same manner, LTA4 can also be weld with glutathione in order to develop LTC4 entailing LTC4 synthase. Following the extracellular metabolism, LTC4 can then convert in LTD4 and LTE4. The triggering of 5-LOX is relied upon the 5-LOX-activating protein (FLAP) (Figure 1) [8, 34].

By managing the phospholipase $\mathrm{A} 2$, arachidonic acid is issued from the membrane phospholipids and turned into 5-HPETE by 5-LOX and 5-LOX activating protein (FLAP). 5-HPETE is able afterwards to pattern either 5-HETE or LTA4. LTA4 then becomes LTB4 or LTC4. LTC4 can then synthetize in cascade LTD4 and LTE4.

CysLT $\left(\mathrm{C}_{4}, \mathrm{D}_{4}\right.$, and $\left.\mathrm{E}_{4}\right)$ are products released from different cells like eosinophils and mast cells involved in the metabolism of arachidonic acid, which have the ability to bind to various cell receptors found in human airways cells, like CysLT1 receptor, located in airway smooth muscle cells and macrophages, as well as on other pro-inflammatory cells, being in this way responsible of local oedema, smooth muscle constriction, and cellular mediated local inflammatory process. 


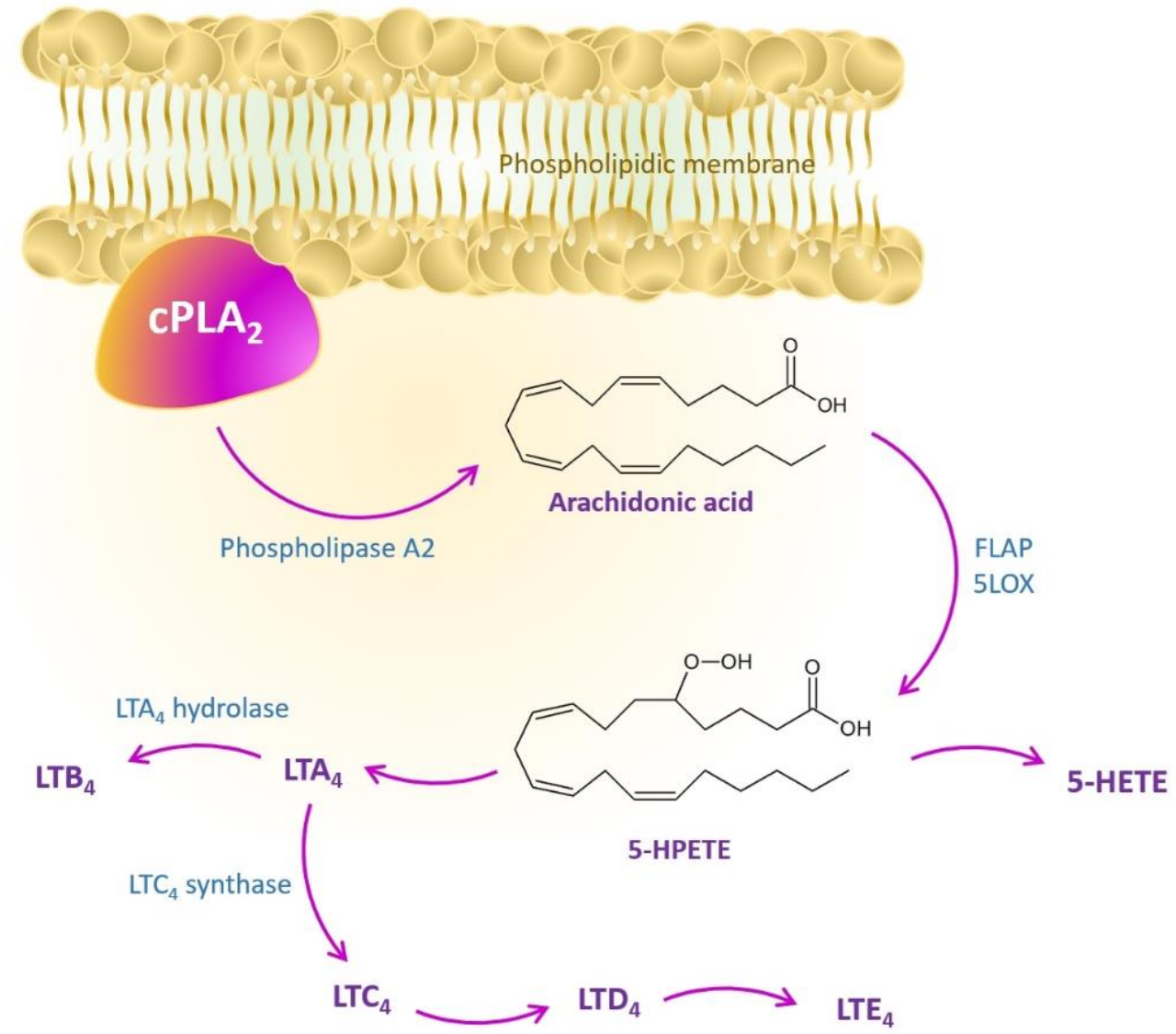

Figure 1.

Metabolic pathway of arachidonic acid via 5-lipoxygenase.

cPLA2: Cytosolic phospholipase A2; 5LOX: 5-Lipoxygenase; FLAP: 5-LOX activating protein; 5-HPETE: 5S-hydroperoxy6E,8Z,11Z,14Z-eicosatetraenoic acid; 5-HETE: 5S-hydroxy-6E,8Z,11Z,14Z-eicosatetraenoic acid; LT: Leukotriene

Montelukast counteracts the action of CysLT, having specific affinity and preferentially binding to CysLT1 receptors, inhibiting the activity of $\mathrm{LT}$, especially $\mathrm{LTD}_{4}$, which is shown to be involved in early and late phase allergic reactions, especially in rhinitis and asthma. By the selective blockade of CysLTD 4 receptors, montelukast is able to inhibit bronchoconstriction produced by the LT release actively (Figure 2) [11, 36].

Various pathogenic stimuli trigger the release of arachidonic acid from membrane structures through cytosolic phospholipase A2 (cPLA2) participation, initiating the 5-lipoxygenase (5-LOX) metabolic pass. 5-LOX catalyses the synthesis of leukotriene A4 starting from the arachidonic acid, afterwards tissue specificity will conduct either to LTB4 or LTC4. Specific transporters encompass these molecules outward the cell, where further transformations to LTD4 and LTE4 can befall and the cell-surface G-protein coupled receptors will be activated, conducting to the biological effects. Montelukast specific blockade of the CysT1 receptor prevents the inflammatory cascade resulting in anaphylactic, oedematous and pro-inflammatory actions.
Despite the early in vitro study of Chiba et al. [9], according to whom CYP3A4, CYP2C9, and CYP2A6 were considered the main microsomes involved in the montelukast metabolism, newer in vivo studies prove that the dominant microsome enrolled in the biotransformation of montelukast in humans is CYP2C8, this pathway accounting about $80 \%$ of its metabolism. The CYP3A4 microsome remains just with minor activity, mediating only the minor metabolite M5a/b formation, and poorly interacting in the elimination of montelukast. [5, 14].

In 2020, FDA required a boxed warning considering serious mental health side effects, as montelukast administration is associated with neuropsychiatric events as anxiety, sleep disturbances, depressive episodes and suicidality. A possible explanation is given by the allergic rhinitis pathological background that is closely allied with an inflammatory response in the hippocampus, the very trigger of these neurologic imbalances. Besides that, the safety profile is good and the drug-to-drug interactions are rare, only cytochrome P450 enzyme inducers, like phenobarbital or rifampin, when co-administered along with montelukast, are requiring specific attention $[13,38]$. 


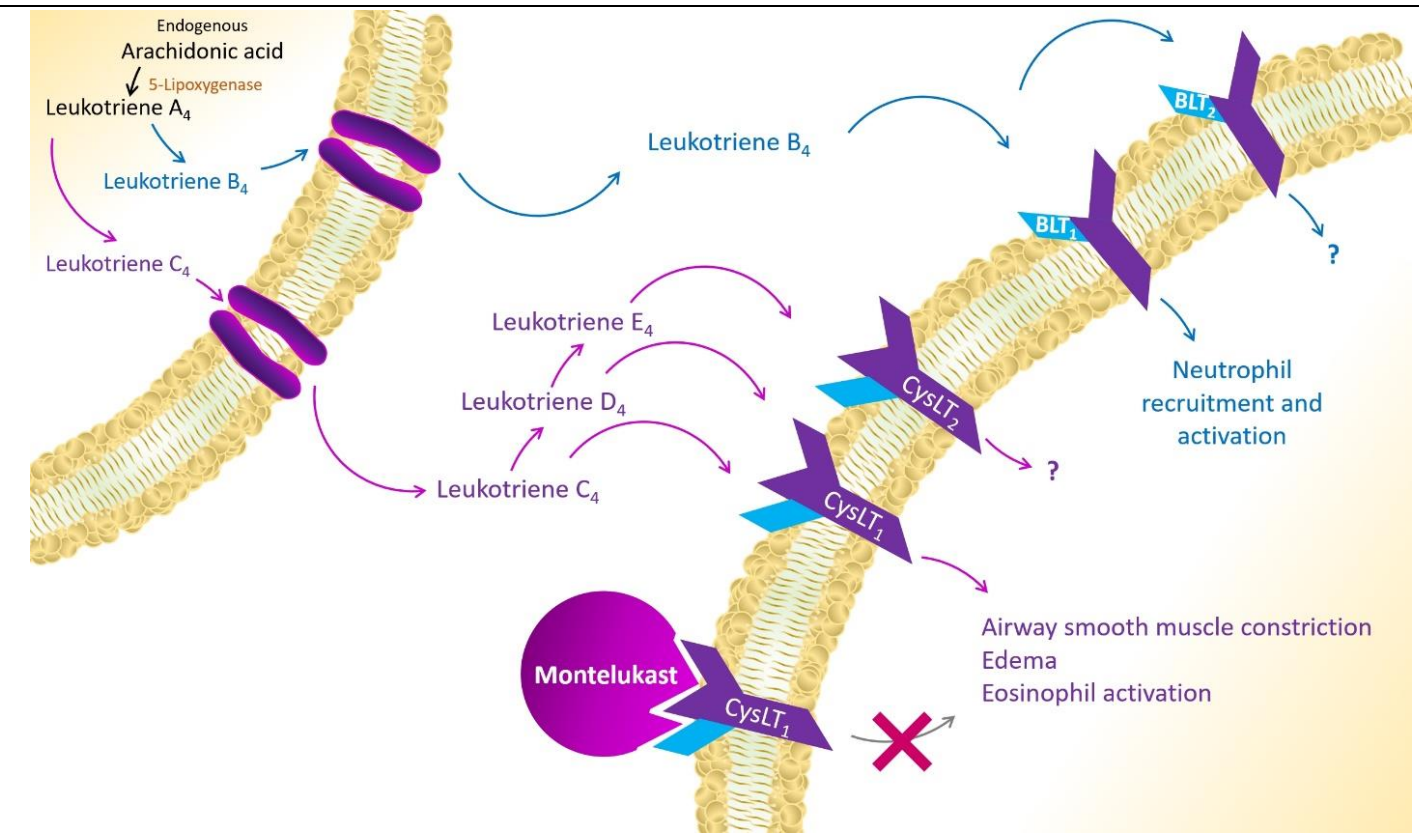

Figure 2.

Biochemical pathways of the synthesis and action of the leukotrienes and sites of action of montelukast BLT, leukotriene B receptor; CysLT, cysteinyl leukotriene receptor

\section{The dysimmune pathogenic background pleading for montelukast use in COVID-19 infection management}

Besides the ongoing attempts to find the best antiviral treatment option for SARS-CoV2 virus from the already known palette of choices, based on previous expertise with other viruses responsible for respiratory distress, physicians involved in COVID-19 pneumonia treatment try to apply the knowledge already obtained during other similar situations. The use of bronchodilators with antiinflammatory potential, as corticosteroids like methylprednisolone, or leukotriene receptor antagonists as montelukast, were proposed in different medical centres facing the COVID-19 infection [12].

The mechanism is based on the alveolar macrophages (AlvMФs), mediated suppression on the cysteinyl leukotrienes (CysLT) pathway genes in type 1 alveolar epithelial cells (T1AECs). The inhibition of the CysLT enzyme pathway proved to decrease the sensitiveness of T1AECs for IAV, this mechanism suggests that the suppression with Montelukast of AlvMФs is the key to IAV infection resistance. Furthermore, the blockade of CysLT receptors in AlvMФs reduces the severity of lethal pneumonia, in laboratory animals. At that time, the use of this blockade suggested that physicians should focus on AlvMФs when dealing with viral infections in general and IAV in particular [16]. Besides, considering COVID-19 infection, the SARS$\mathrm{CoV} 2$ virus accesses the host cells through the enzyme angiotensin-converting enzyme 2 (ACE2), using its "spike" surface glycoprotein to associate to ACE2 and entering by this way in the host cells which are most abundantly in ACE2, like alveolar cells of the lungs. By blocking CysLT receptors, the SARS-CoV2 affinity ACE2 alveolar cells is diminished [2].

This mechanism creates the premise of montelukast use in COVID-19 infection, the inflammatory lung distress produced by SARS-CoV2 being potentially counteracted by targeting the CysLT pathway and blocking the receptors for CysLT metabolites in T1AECs responsible for $\mathrm{O}_{2}$ exchange [8].

The antiviral usefulness of montelukast was also demonstrated while handling the 2015 outbreak produced by Zika virus (ZIKV) infection, manifested with neurological complications, like foetal microcephaly. No vaccines or therapeutic drugs with acceptable safety profiles were approved since then to treat ZIKV infection, and the discovery of medications to safely use during pregnancy is still a concern issue. Montelukast, acknowledging its safety profile in pregnant women, display antiviral efficacy against the ZIKV infection in both in vitro and in vivo conditions by disrupting the virions entirety, discharging the viral genomic RNA, with irreversible implications for the viral replicative cycle [8].

Montelukast proves to inhibit not only the ZIKV infections, but also other flaviviruses, including Dengue virus 2 (DENV-2) and Yellow Fever virus (YFV 17D). It also protects mice from lethal ZIKV infection and blocks the vertical transmission of ZIKV from pregnant mice [18]. On the genomic RNA release of the un-enveloped RNA enterovirus 71 (EV71), no effect was proven, but antiviral activity has been revealed against the vesicular stomatitis virus (VSV), which is an enveloped non-flavivirus, thus suggesting 
FARMACIA, 2020, Vol. 68, 4

that montelukast probably targets the viral shell pending the lipid membrane [8], this making a possible analogy with SARS-CoV2 virus.

Contrariwise, the pharmacological action of montelukast favours its antiviral effect by an attendant antiviral mechanism. LT release induced by viral infections mediate the vascular leakage through mast cell activation, causing vascular permeability, organ haemorrhages, and plasma leakage into the tissues, the main attributes of Dengue shock syndrome (DSS) and Dengue haemorrhagic fever (DHF) [1], mechanisms potentially involved in severe SARS-CoV2 infection. In SARSCoV2 infection, by the LT blockade, montelukast prevents the cytokines release and the subsequent pulmonary damage.

Following the above pathogenic judgments, nowadays, some clinicians propose montelukast for COVID19 infection, recommending a loading dose of montelukast of $60 \mathrm{mg}$ followed by a $10 \mathrm{mg} /$ day for 15 days as safe and effective. The drug has been tested at doses of $900 \mathrm{mg} /$ day, and a clinical trial is ongoing with a dose of $200 \mathrm{mg} / \mathrm{day}$ [11].

The hypothesis of montelukast ability to reduce the risk of COVID-19 infection was assessed in an interesting retrospective observational clinical study on asthmatic elderly patients already treated with montelukast for 12 months, in order to better control the asthmatic episodes of severe cases, which were treated previously with inhalatory glucocorticoids and long lasting beta-agonists. The results of the study are absolutely promising as the occurrence of COVID-19 cases among the montelukast treated patients was significantly reduced, compared to the non-montelukast group that had similar age, comorbidities, other anti-asthmatic therapies and social profile [4].

One possible concern on montelukast use in COVID-19 infection would be the possible drug-to-drug interactions, knowing from HIV treatment experience that all directacting antivirals have many drug-to-drug interactions, due to their metabolic pathways. From this perspective, the montelukast use in COVID-19 infection looks safe, this being mainly metabolized by CYP2C 8 and to a lesser extent by the CYPs 3A4 and 2C9 [5, 16]. The antivirals like darunavir and lopinavir recommended by the current guidelines to treat SARS-CoV2 infection have only partially and limited inhibiting action on the CYP3A4, with no action on the main metabolic pathway involving CYP2C8 [2].

Ritonavir dosed as a pharmacokinetic booster for the previous two, is a weak inhibitor of CYP2C8, but without major impact [34, 38]. Due to montelukast safety profile, no a priori dosage adjustment is recommended for darunavir/ritonavir or lopinavir/ ritonavir combinations $[34,38]$.

No interactions were reported between montelukast and tocilizumab or hydroxychloroquine [34].
In silico molecular studies assessing montelukast therapeutical and preventive biological effects in SARS-CoV2 infection

In addition to all stated mechanisms and complementary actions proven by montelukast administration in different pathological scenarios, a new assessing opportunity has emerged, in order to predict the ability of a molecule to act in a specific manner, at a molecular level. Computational studies represent, nevertheless, one of the strategies used to discover new possibilities for overcoming the COVID-19 health burden, by screening existing databases of potential drugs that can target human immune system mechanisms or the coronavirus mechanistic approach, either by inhibiting the biosynthesis of the viral RNA, modulating the activity of sine qua non enzymes necessary in the replication process, or even changing the affinity of the virus for the human cell receptors and interacting with the inner viral assembly procedure by structural protein interplay $[18,28]$.

In silico analysis was performed on different proteins encoded by the incriminated viral genes, for establishing, by homology modelling all the proteic structures as the main protease, helicase, RNA polymerase, viral papain like protease and other [30].

The human enzymatic proteins ACE2 and type-II transmembrane serine protease (TMPRSS2), all together with the viral proteins were assessed by virtual ligand screening, for all the therapeutic molecules in the databases, in order to predict the most effective molecules for prevention and treatment purposes [2].

The resulting promising agents were from different pharmacological classes: anti-virals, anti-bacterials, and anti-asthmatics. A remarkable profile was obtained for montelukast which exhibited low binding energy for the 3C-like main protease, fitting perfectly into the active pocket of this protein essential for the life cycle of the coronavirus [30]

The anti-asthmatic drug displayed perfect hydrophobic-hydrophobic and hydrogen interactions at the site of the substrate-binding pocket of the main protease in other molecular docking recent studies $[17,32]$. The outcome will be the inhibition of the viral replication and the ability to modulate the disease evolution by the virulence silencing.

The new findings in the light of computational procedures convey for montelukast potential antiviral features that complement its anti-inflammatory effects exerted by blocking the CysLT receptors and inhibiting the cytokines expression in activated macrophages.

\section{Conclusions}

Old therapeutic agents like montelukast find new indications for COVID-19 infection, since specific antiviral drugs or efficient vaccines are not yet available. First-line physicians dealing with COVID-19 
FARMACIA, 2020, Vol. 68, 4

infection are continuously challenged by the pandemic magnitude, profound and irreversible consequences and its mortality rates, making efforts to apply their expertise and medical knowledge to combat the infection by already marketed drugs. Off-label indications for many drugs approved for other medical indications like diseases with similar pathogenic background could lead to therapeutic success in COVID-19 infection, the clinical practice providing the selection of the best treatment options for patient's treatment.

\section{Conflict of interest}

The authors declare no conflict of interest.

\section{References}

1. Ahmad A, Waseem T, Butt N, Randhawa F, Malik U, Shakoori T, Montelukast reduces the risk of dengue shock syndrome in dengue patients. Trop Biomed., 2018; 35: 1115-1122.

2. Arsene AL, Dumitrescu IB, Drăgoi CM, Udeanu DI, Lupuliasa D, Jinga V, Drăgănescu D, DinuPîrvu CE, Burcea Dragomiroiu GTA, Blejan IE, Moisi RE, Nicolae AC, Moldovan H, Popa DE, Velescu BS, Ruţă S, A new era for the therapeutic management of the ongoing COVID-19 pandemic. Farmacia, 2020; 68(2): 185-196.

3. Bourouiba L, Turbulent gas clouds and respiratory pathogen emissions: Potential implications for reducing transmission of COVID-19. JAMA, 2020; 323(18): 1837-1838.

4. Bozek A., Winterstein J, Montelukast's ability to fight COVID-19 infection. Journal of Asthma, 2020, doi:10.1080/02770903.2020.1786112.

5. Cardani A, Boulton A, Kim TS, Braciale TJ, Alveolar macrophages prevent lethal influenza pneumonia by inhibiting infection of type- 1 alveolar epithelial cells. PLoS Pathog., 2017; 13(1): 1-25.

6. Catrinoiu D, Ceriello A, Rizzo M, Serafinceanu C, Montano N, Pantea Stoian A, Udeanu DI, Jinga V, Iorgulescu G, Dumitrescu IB, Diabetes and reninangiotensin-aldosterone system: implications for COVID-19 patients with diabetes treatment management. Farmacia, 2020; 68(3): 377-383.

7. Chen N, Zhou M, Dong X, Qu J, Gong F, Han Y, Qiu Y, Wang J, Liu Y, Wei Y, Xia J, Yu T, Zhang X, Zhang L, Epidemiological and clinical characteristics of 99 cases of 2019 novel coronavirus pneumonia in Wuhan, China: a descriptive study. Lancet, 2020; 395(10223): 507-513.

8. Chen Y, Li Y, Wang X, Zou P, Montelukast, an antiasthmatic drug, inhibits Zika Virus infection by disrupting viral integrity. Front Microbiol., 2020; 10: $1-14$

9. Chiba M, Xu X, Nishime JA, Balani SK, Lin JH, Hepatic microsomal metabolism of montelukast, a potent leukotriene D4 receptor antagonist, in humans. Drug Metab Dispos., 1997; 25(9):1022-1031.

10. Feng S, Shen C, Xia N, Song W, Fan M, Cowling BJ, Rational use of face masks in the COVID-19 pandemic. Lancet Respir Med., 2020; 8(5): 434-436.
11. Fidan C, Aydoğdu A, As a potential treatment of COVID-19: Montelukast. Med Hypotheses, 2020; 142: 109828, doi: 10.1016/j.mehy.2020.109828.

12. Guo G, Ye L, Pan K, Chen Y, Xing D, Yan K, Chen Z, Ding N, Li W, Huang H, Zhang L, Li X, New Insights of Emerging SARS-CoV-2: Epidemiology, Etiology, Clinical Features, Clinical Treatment, and Prevention. Front Cell Dev Biol., 2020; 8: 410, doi: 10.3389/fcell.2020.00410.

13. Hoxha M, Lewis-Mikhael AM, Bueno-Cavanillas A, Potential role of leukotriene receptor antagonists in reducing cardiovascular and cerbrovascular risk: A systematic review of human clinical trials and in vivo animal studies. Biomed Pharmacother., 2018; 106: 956-965.

14. Karonen T, Neuvonen PJ, Backman JT, CYP2C8 but not CYP3A4 is important in the pharmacokinetics of montelukast. Br J Clin Pharmacol., 2012; 73(2): 257-267.

15. Lai CC, Shih TP, Ko WC, Tang HJ, Hsueh PR, Severe acute respiratory syndrome coronavirus 2 (SARS-CoV-2) and coronavirus disease-2019 (COVID-19): The epidemic and the challenges. Int J Antimicrob Agents., 2020; 55(3): 105924, doi: 10.1016/j.ijantimicag.2020.105924.

16. Letko M, Marzi A, Munster V, Functional assessment of cell entry and receptor usage for SARS-CoV-2 and other lineage B betacoronaviruses. Nat Microbiol., 2020; 5(4): 562-569.

17. Li H, Zhou Y, Zhang M, Wang H, Zhao Q, Liu J, Updated Approaches against SARS-CoV-2. Antimicrob Agents Chemother., 2020; 64(6): 1-7.

18. Lok SM, Costin JM, Hrobowski YM, Hoffmann AR, Rowe DK, Kukkaro P, Holdaway H, Chipman P, Fontaine KA, Holbrook MR, Garry RF, Kostyuchenko V, Wimley WC, Isern S, Rossmann MG, Michael $\mathrm{SF}$, Release of dengue virus genome induced by a peptide inhibitor. PLoS One, 2012; 7(11): 1-8.

19. Lu CC, Chen MY, Lee WS, Chang YL, Potential therapeutic agents against COVID-19: What we know so far. J Chin Med Assoc., 2020; 83(6): 534-536.

20. Lu H, Drug treatment options for the 2019-new coronavirus (2019-nCoV). Biosci Trends, 2020; 14(1): 69-71.

21. Ortiz-Prado E, Simbaña-Rivera K, Gómez-Barreno L, Rubio-Neira M, Guaman LP, Kyriakidis NC, Muslin C, Jaramillo AMG, Barba-Ostria C, Cevallos-Robalino D, Sanches-SanMiguel H, Unigarro L, Zalakeviciute R, Gadian N, López-Cortés A, Clinical, molecular, and epidemiological characterization of the SARSCoV-2 virus and the Coronavirus Disease 2019 (COVID-19), a comprehensive literature review. Diagn Microbiol Infect Dis., 2020; 98(1): 1-31.

22. Osuchowski MF, Aletti F, Cavaillon JM, Flohé SB, Giamarellos-Bourboulis EJ, Huber-Lang M, Relja B, Skirecki T, Szabó A, Maegele M, SARS-CoV2/COVID-19: Evolving Reality, Global Response, Knowledge Gaps, and Opportunities. Shock, 2020: doi: 10.1097/SHK.0000000000001565.

23. Sharma A, Tiwari S, Deb MK, Marty JL, Severe acute respiratory syndrome coronavirus-2 (SARSCoV-2): a global pandemic and treatment strategies. Int J Antimicrob Agents., 2020: 106054, doi: 10.1016/j.ijantimicag.2020.106054. 
24. St John AL, Rathore AP, Raghavan B, Ng ML, Abraham SN, Contributions of mast cells and vasoactive products, leukotrienes and chymase, to dengue virus-induced vascular leakage. Elife, 2013; 2: 1-18.

25. Stoian AP, Catrinoiu D, Rizzo M, Ceriello A, Hydroxychloroquine, COVID-19 and diabetes. Why it is a different story. Diabetes Metab Res Rev., 2020: e3379, doi: 10.1002/dmrr.3379.

26. Stoian AP, Papanas N, Prazny M, Rizvi AA, Rizzo M, Incretin-Based Therapies Role in COVID-19 Era: Evolving Insights. J Cardiovasc Pharmacol Ther., 2020: 1074248420937868, doi: 10.1177/1074248420937868.

27. The Novel Coronavirus Pneumonia Emergency Response Epidemiology Team, Vital surveillances: The epidemiological characteristics of an outbreak of 2019 novel coronavirus diseases (COVID-19) China, 2020. China CDC Weekly, 2020; 2(8): 113-122.

28. van Doremalen N, Bushmaker T, Morris DH, Holbrook MG, Gamble A, Williamson BN, Tamin A, Harcourt JL, Thornburg NJ, Gerber SI, Lloyd-Smith JO, de Wit E, Munster VJ, Aerosol and surface stability of SARS-CoV-2 as compared with SARS-CoV-1. N Engl J Med., 2020; 382(16): 1564-1567.
29. Velavan TP, Meyer CG, The COVID-19 epidemic. Trop Med Int Health., 2020; 25(3): 278-280.

30. Wu C, Liu Y, Yang Y, Zhang P, Zhong W, Wang Y, Wang Q, Xu Y, Li M, Li X, Zheng M, Chen L, Li H, Analysis of therapeutic targets for SARS-CoV-2 and discovery of potential drugs by computational methods. Version 2. Acta Pharm Sin B, 2020; 10(5): 766-788.

31. Ye Q, Wang B, Mao J, Fu J, Shang S, Shu Q, Zhang T, Epidemiological analysis of COVID-19 and practical experience from China. J Med Virol., 2020; 92(7): 755-769.

32. Zhang LP, Wang M, Wang Y, Zhu J, Zhang N, Focus on a 2019-novel coronavirus (SARS-CoV-2). Future Microbiol., 2020: 10.2217/fmb-2020-0063, doi: $10.2217 / \mathrm{fmb}-2020-0063$.

33. https://coronavirus.jhu.edu.

34. https://www.drugs.com.

35. www.cdc.gov

36. www.who.int.

37. www.clinicaltrials.gov.

38. www.fda.gov. 